\title{
Challenges in Making Landscape Waste Dumping Site in Universiti Teknologi Malaysia
}

\author{
Ida shaheera binti Bakhtiar ${ }^{*}$, Norhidayah binti Md. Yunus ${ }^{1}$, Mohd. Haizal bin \\ Jamaluddin ${ }^{1}$, Muhammad Aizi bin Mat ${ }^{1}$, Muhammad Noor bin Harun ${ }^{1}$ \\ ${ }^{1}$ Kolej Rahman Putra, Universiti Teknologi Malaysia, Skudai, Johor 81310, Malaysia \\ *Corresponding author. Email: idasheera@gmail.com

\begin{abstract}
Management of landscape waste dumping site is refer to the way we manage a waste that produces by landscape provided around Universiti Teknologi Malaysia (UTM). Landscape waste management also refers to the management in dumping site. The area of landscape waste dumping site undergoes significant changes in UTM. This study was conducted to study the challenges of landscape waste dumping site management in UTM. In addition, this study is to identify landscaping waste initiatives practiced in UTM. This study only involves the management of landscaping wastes in UTM. This study was conducted by interviewing five respondents who have interest in landscaping management at UTM. Data collection will be analyzed qualitatively. As a result of these studies, there are four challenges, namely financial resources, lack of workforce and expertise, contractor monitoring and the site itself. This study can be a reference to the university on the challenges faced by the management of landscape units in managing landfills and landscaping wastes in UTM. Several proposals have been submitted at the end of the study to ensure that landscape waste disposal management can be improved more effectively and efficiently in the future.
\end{abstract}

\section{Keywords: landscape waste, dumping site management, environment}

\section{INTRODUCTION}

The increasing of population and tourism has brought the solid waste management becomes burden especially in University. The increasing population of students entered university made some changes as realization about waste management is still lacking.

Solid waste generally refers to waste or waste which is not in the form of liquid nor gas. Disposal of solid waste requires a good and sustainable management system for the preservation of the environment. Solid waste management is one of the key issues for developing countries. This is because the method of reliance on landfills is no longer effective due to the increase in the amount of solid waste per day as well as the lack of landfill. Apart from that, the disposal and collection of solid waste is an important matter that not only involves the issue of national development, but is closely related to the public health aspect that touches the everyday life of the people.

According to reports of the Ninth Malaysia Plan 20062010, the amount of solid waste generated in Peninsular Malaysia increased from 16,200 tonnes per day in 2001 to
19,100 tonnes per day in 2005 (Economic Planning Unit, 2005). Subsequently, the Ministry of Urban Wellbeing, Housing and Local Government (KPKT) (2008) estimates the amount of this waste to increase to 23,000 tonnes in 2010 and continues to increase to 30,000 tonnes per day by 2020 .

On average, Malaysians generate solid wastes of 0.8 kilogram a day with an increase of $2.5 \%$ per annum (KPKT, 2008). These solid wastes include domestic solid waste, public solid waste, and solid waste from institutions, solid waste imports, commercial solid waste and industrial solid waste (PPSPPA, 2015). Only in Kuala Lumpur and Selangor, the statistics released by the Solid Waste and Public Cleansing Corporation (PPSPPA) in 2008 showed 1.8 million tonnes of domestic waste; and it increased to 1.9 million tonnes in 2009 (Special Report, 2011). Of the total solid waste, food waste is the major composition that contributes up to $45 \%$ apart from waste such as plastic, paper, metal, glass and others (Economic Planning Unit, 2005).

Solid waste management involves five major elements ranging from generation, storage, collection / transportation, recovery / treatment, and disposal (PPSPPA, 2015). Due to the wide range of elements, solid waste management needs to be a holistic improvement for 
the benefit of the environment and the public. On this basis, the government restructured solid waste management through privatization from the interim period in 1998 until fully enforced in 2010. For the purpose of this exercise, in 2007, the Government gazetted the Solid Waste Management and Public Cleansing Act (Act 672).

However, the cost of waste management also requires a high cost from collecting, collecting, and transporting to disposal. Our country does not have enough budget to manage the wastes that are increasingly growing. Every day as much as 37,000 tons of garbage is produced and about 13.5 tons each year. The cost of the waste management is estimated at RM2.2 billion a year. (Utusan Online, 2017).

Solid waste management is actually a global issue. In the Republic of China, for example, various initiatives have been implemented to develop solid waste quantity reduction projects such as the introduction of the Packaging Act, its composting and marketing programs. Accordingly, the Chinese government has converted 10 percent organic solid (solid) into compost and the remaining 90 percent is sent to the landfill (World Bank, 2005). There are various methods that can be used and identified for managing solid waste so that it does not affect the environment and safeguard the environment. Some of the methods that have been practiced up to the world level are the $3 \mathrm{R}$ method of reducing, reuse, recycling and recycling. This method can be categorized as the easiest method to practice regardless of the age range.

The main thing to be aware of in terms of solid waste is the disposal site that has been provided. The area provided should be well regulated to manage the solid waste so that it does not affect the landfill. However, some landfill sites have been closed. A total of 91 landfill sites operating while 136 landfills have been closed (Solid Waste Reporting System, SWCorp, 2018).

In 2012, Sustainable Development Goals (SGDs) were established at the United Nation conference on sustainable development in Rio de Janeiro. The objective is to generate a set of universal goals that meet the urgent challenges of the environment, politics and economy that are facing today. (United Nation Development Program, 2017).

Sustainable Development Goals (SGDs) are divided into 17 goals, including waste. The 12th goal is about the responsibility of consumption and production. To achieve goal 12 requires a strong national framework for sustainable use and production integrated into national and sector plans, sustainable business practices and consumer behavior, along with compliance with international norms on chemicals and wastes.

Promoting economic growth from the use of natural materials is fundamental to sustainable development. However, global figures showed a worsening trend where domestic consumption (the amount of natural resources used in the economic process) increased from $1.2 \mathrm{~kg}$ to $1.3 \mathrm{~kg}$ per unit from gross domestic product since 2000 to 2010. Total domestic material consumption also increased in the same time, from 48.7 billion tonnes to 71.0 billion tonnes (United Nation, 2017)

\section{LITERATURE REVIEW}

In general, landscapes refer to the environment experienced by every individual. It has broad meanings covering the geological structure of the land, flora and fauna, patterns of human activity such as plantation, forestry, settlement and industrialization. It is also an interaction between natural resources and human needs which encompasses admiring the beauty and aesthetic value, architecture and overall ecology and history of an area.

In the context of National Landscape Policy, landscapes mean an ecosystem that includes nature and nature. Natural landscapes include terrain, geology, water bodies as well as flora and fauna. Built-in landscapes include settlements, plantation areas, open spaces, public parks, public spaces and heritage and tourism areas that include the beauty and aesthetic value, architecture and overall ecology and history of an area.

\subsection{Definition of Landscape Waste}

Landscape waste defined as the result of parks, plants, environmental parks, and so on. The main components of the page waste include grass keratin, dry and fresh leaves, root and shoots of small plants and tree branches. Uncontrolled waste disposal lands will cause odor in the dumps (Bary et al., 2005; Lopez et al., 2010).

Landscape waste is also defined as plant material as a result of gardening, horticulture, agriculture, landscaping or land clearing, including materials such as tree decorations and shrubs, permanent plants, grass cuttings, leaves, trees and stumps. The main sources of leaves and waste are from residential homes, schools, businesses, golf courses and municipal parks (The Leaf and Yard Waste Diversion Technical Committee of Alberta, 2018).

In addition, landscape residues are also produced from gentle landscape and plant maintenance (Greening, Landscape, and Tree Management Section, Bureau, 2014). Landscape waste is also known as garden or garden waste by banana stems, dry leaves, twigs, flowers and coconut fronds (SWM Environment, 2016).

The residual landscapes intended for this study are references to the remnants generated from the landscaping of Universiti Teknologi Malaysia as an institution in accordance with the definition set forth by The Leaf and 
Yard Waste Diversion Technical Committee of Alberta, 2018 and also the remaining garden or garden intended by SWM Environment.

\section{METHODOLOGY}

The study was conducted to identify the challenges in managing landscape waste dumping site in Universiti Teknologi Malaysia. To achieve the objectives of the study, this study will be conducted through two phases. In first phase, the researcher will examine the initiatives of landscape waste dumping site management in UTM.

Therefore, matters relating the initiatives of management landscape waste dumping site will be explained in the literature review. Thus, the researcher will use the content analysis method to provide explanation, explanations on the initiatives of landscape waste dumping site management. Content analysis is an information analysis tool that is done by researching and processing information from written materials such as books, journals, thesis, newspapers and other documentation materials for information pertaining to the first objective.

While in second phase, the researcher chooses to conduct qualitative analysis to examine the challenges in managing landscape waste dumping site in UTM. Therefore, the researcher will be involved with the data collection process to collect data related to the research conducted and then answer the questions that arise in the case study. The data collected will be processed into information in the form of assessment materials to achieve the objectives of the study as specified.

In this case, researcher chooses to apply semi-structure interview which is question for interview is more flexible and it can be added or modified during the interview session.

Table 1: division of interview question

\begin{tabular}{|l|l|}
\hline Section & \multicolumn{1}{|c|}{ Item } \\
\hline$A$ & Respondent Background \\
\hline$B$ & $\begin{array}{l}\text { Initiatives of landscape waste } \\
\text { dumping site management }\end{array}$ \\
\hline$C$ & $\begin{array}{l}\text { Challenges in managing landscape } \\
\text { waste dumping site in UTM }\end{array}$ \\
\hline
\end{tabular}

Respondents for this interview determine by purposive sampling technique with criteria where only person that involve with this case and have information regarding this issue that can be respondent. This is important in order to make sure information received is true and not biased to any parties. Purposive sample also known as judgmental and it is a type of non-random sample that selected based on the opinion of expert (Deming, 1990).

The number of respondents for this research is 5 and it is applicable since there are no specific numbers of respondents for qualitative analysis. Alternatively, purposive sampling method may prove to be effective when only limited numbers of people can serve as primary data sources due to the nature of research design and aims and objectives (John Dudovskiy, 2018)

To analysis the information and achieve the both objective of this study, researcher use descriptive analysis in order to extract important data.

\section{RESULTS AND FINDINGS}

Analysis is based on the information obtained from interviews conducted with selected respondents to achieve the research objectives. There are two analyses that have been made in order to make sure that both objectives are achievable.

The first analysis is to achieve the first objective of study which is to identify the method of landscape waste dumping site management in UTM. Based on the interviews conducts, researchers found that there are initiatives of landscape waste management that has been implemented in UTM. Table 2 refer to the initiatives of landscape waste dumping site management in UTM .

Table 2: Method of Landscape Waste Dumping Site management in UTM

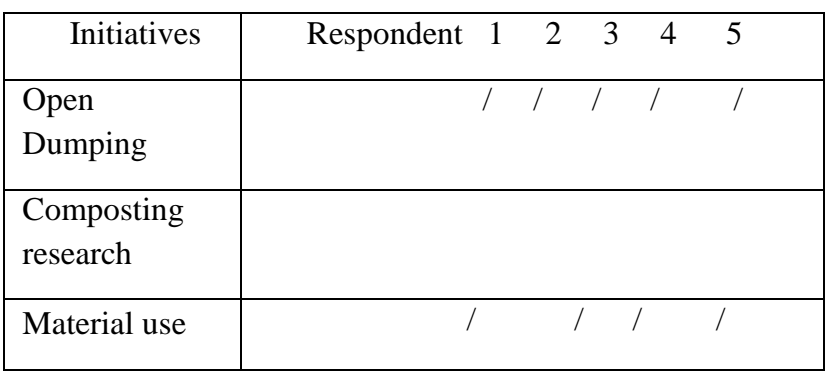

Table 2 shows the method of landscape waste dumping site management in UTM. According to R1, R2 and R3 landscape residuals in UTM are used as compost fertilizer. The method of composting is naturally using mixed ingredients such as 'water cunning', horse stools, food waste and ammonia to accelerate the process of decomposition of the landscaping. Compost produced is only for landscape use around UTM campus.

For the management of open dumping method, Respondent 2, Respondent 3, Respondent 4 and 
Respondent 5 state that the open dumping method of landscape waste is one of the methods to manage landscaping wastes in UTM. Based on Respondent 2 shared in the beginning of 2018, the UTM landscaped landfill site was divided according to the latest division of the UTM campus zone of four zones for the entire campus. Through this zone division, the responsible contractor should remove the landscaping according to the designated zones at the UTM landscape waste site and have to go through four phases before being reusable compost.

According to Respondent 4 and Respondent 5 landscape residues are used as research material. However, the use of waste landscaping required only involves dry leaves with certain content. The dried leaves are used as fuel after several processes and they become substitutes that can save costs if they use other technologies for research purposes.

Next to achieving the second objectives of this study, researcher will analyses information in relation to measures to overcome problems occur as a result of interviews conducted. This analysis should be made with a view to the completion of the steps that have been taken and the steps that can be taken by the parties involved. Based on interviews conducted with the parties involved, the data provided and the result of the interview, the researchers found that there are various challenges from various aspects in the implementation of landscape waste dumping site management in UTM. Based on table 3 shows the respondents' views of the landscape waste dumping site management challenge in UTM.

Table 3: Respondent views of the challenges of landscape waste dumping site management

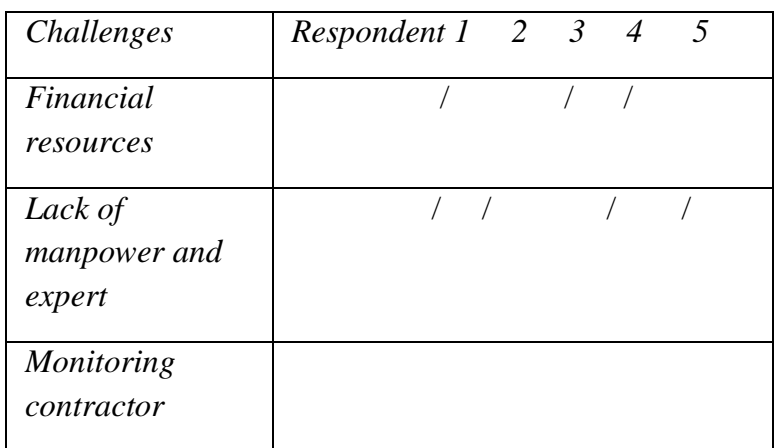

The financial aspect is a major challenge is due to limited financial resources resulting in limited management in managing landscaping at UTM. According to Respondent 4 , the lack of financial resources is also a source of ineffective management because it is unable to manage the landscaping by using high technology. To use high technology in landscape waste management, it costs a lot. However Respondent 1, Respondent 2, Respondent 3 and
Respondent 5 believe that high technology utilization can contribute to the effectiveness of landscape waste management at UTM landfill.

While Respondent 2 states that the lack of financial resources is for the purpose of researching the final compost fertilizer product to be commercialized and to be a source of income to the university. The required research is to determine the content and quality of compost fertilizers produced

Sufficient workforce will contribute to the creation of a goal to be achieved. Meanwhile, expert energy refers to the energy that has a profound knowledge of a field. As a research university, lack expertise issues should not exist because UTM has produced many successful researchers. Likewise in the management of landscape waste, Respondent 2 and Respondent 3 state that the challenge of management of landscaping wastewater at UTM is the lack of expertise.

According to Respondent 2, landscape units require special researchers in waste management to help overcome the problem of landscape waste management from more innovative research aspects. Expertise should be placed under the landscape unit to focus on other uses of the waste generated within UTM.

According to Respondent 3, the lack of workforce at the operational level is also a challenge faced in the implementation of landscape waste management in UTM. This is because R3 states that the monitoring carried out at the disposal site at UTM is once a week or two weeks. Sufficient manpower in the operation should also contribute to the effectiveness of the management of the remaining landscapes itself

According to Respondent 2, Respondent 3 and Respondent 4 , the challenges faced in the implementation of landscape waste management are also from the aspect of contractor monitoring. Landscape waste managers cannot monitor the entire movement of contractors because those who work under the contractor involve many employees involved in every zone within UTM. The main challenge in contractor monitoring is from the collection stage to the isolation stage. The isolation stage is to ensure that the remaining landscapes do not mix with other wastes.

According to Respondent 2, there is also a problem between contractors among contractors and there has been an issue of sabotage among contractors. The issue of sabotage occurs when landslide disposal sites are divided according to their respective zones within UTM, there are irresponsible contractors disposing of landscaping wastes in inappropriate zones. That does not raise the issue until there is a waste mix other than the remaining landscapes found in designated zones at the disposal site. This is a 
challenge in managing landscaping waste when the parties responsible for managing waste on behalf of UTM have internal problems.

According to Respondent 1, Respondent 2 and Respondent 5 , the landscape waste disposal site is also a challenge faced in the implementation of landscaping management in UTM. This is because according to Respondent 1, the open drainage conditions and no boundary walls cause the waste of the dumped lands to be freely. According to Respondent 2 , the location of the landfill site located far from administrative and academic buildings has led the contractor to take an unhealthy attitude towards managing landscaping at UTM.

\section{CONCLUSION}

In conclusion, this study is to look at the method of landscape waste dumping site management in UTM applied by the parties involved in ensuring the land use of the landfill site is optimally used and thereby enhances the sustainability of the campus. This study also looks at the causes of the change in the extent of the landfill site at UTM which affects the land use and surrounding land. Hence, the views and opinions of certain parties are taken into account in order to find out the landscaping utilization initiatives undertaken at UTM.

Landscape waste management needs to be seen as a management that requires research from all universities because UTM is one of the research universities in Malaysia in line with the established mission of being a leader in human capital development and innovative technology that will contribute to the creation of nation's wealth.

The impact of increased construction and new areas in UTM led to the increase in landscape waste generation and the increased change in the area of the dump site has become an issue in creating a sustainable and prosperous campus development. Landscape waste management needs to be emphasized as almost 70 percent of UTM area is a green area that will produce waste. This large number of green areas will contribute to the income of the university if all parties see that landscaping waste has its own value if managed efficiently and effectively. Undoubtedly, changes in landscape management if done more comprehensively will cost substantially in terms of technology utilization, but once it is implemented indirectly it will minimize the cost of maintaining landscaping landfills.

\section{REFERENCES}

[1] Ali, H., Dermawan, D., Ali, N., Ibrahim, M., \& Yaacob, S. (2012). Masyarakat dan amalan pengurusan sisa pepejal ke arah kelestarian komuniti: Kes isi rumah wanita di Bandar Baru Bangi, Malaysia. Retrieved from http://journalarticle.ukm.my/5515/1/artikel6.pdf

[2] Dasar Pengurusan Sisa Pepejal Negara (2016). Jabatan Pengurusan Sisa Pepejal Negara, Kementerian Perumahan dan Kerajaan Tempatan.Retrieved from www.jpspn.kpkt.gov.my

[3] Fauzi Mohd Shariff, A., \& Darul Ehsan, S. (n.d.). Kepentingan Pengurusan dan Penyelenggaraan Taman. Retrieved from http://ikpkt.kpkt.gov.my/nota/landskap/PL09/Pen genalan.pdf

[4] Guidelines on Yard Waste Reduction and Treatment Greening, Landscape and Tree Management Section Development Bureau The Government of the Hong Kong Special Administrative Region. (2014). Retrieved from http://www.enb.gov.hk/en/files/FoodWastePolicy Eng.pdf

[5] Haslinda Mohd Anuar, H. A. (2015). Sisa Pepejal dan Pembersihan Awam: Pengurusan dan Perundangan. Solid waste Solution Journal.

[6] Jabatan Pengurusan Sisa Pepejal Negara. (2016, September 7). Dasar Pengurusan Sisa Pepejal. Retrieved from http://jpspn.kpkt.gov.my

[7] mStar. (2015, Ogos 27). UPM Terus Inovatif Aplikasi Teknologi Urus Sisa Makanan. Retrieved from https://www.mstar.com.my/lokal/semasa/2015/08 /27/upm-inovasi-teknologi-urus-sisa-makanan

[8] Landskap Negara Kementerian Perumahan, J., \& Tempatan, K. (n.d.). Dasar Landskap Negara. Retrieved from www.kpkt.gov.my/jln

[9] Manu \& Kumar, R \& Garg, Anurag. (2013). Physical and chemical characterization of yard waste. International Journal of Applied Engineering Research. 16. 1891-1896.

[10] Penjagaan Alam Sekitar: Cabaran Dan Pengurusan Sisa Pepejal Domestik. (n.d.). Retrieved December 5, 2018, from https://www.malaysian-ghostresearch.org/pengurusan-sisa-pepejal-domestik/

[11] Perancangan Bandar, J., Desa, D., \& Malaysia, S. (n.d.). Panduan Pelaksanaan Inisiatif Pembangunan Kejiranan Hijau. Retrieved from www.townplan.gov.my

[12] Shiel, C. L. (2016). Evaluating the engagement of universities in capacity building for sustainable development in local communities. In Evaluation and program planning (pp. 123-134).

[13] Siri Panduan Ringkas Penyenggaraan Berjadual Kebersihan Halaman, Kawasan dan Landskap. (n.d.). Retrieved December 5, 2018, from http://pembangunan.eng.usm.my/web/landskap/

[14] SWM Environment. (2013, September 11). Penguatkuasaan Pengasingan Sisa Pepejal. Retrieved from www.swm-environment.com 
[15] Thomas L. Richard., Nancy M.Dickson \& Sally J.Rowland (2000). Yard Waste Management: A Planning Guide for New York State. Retrieved from

http://cwmi.css.cornell.edu/yardwastemanual.pdf

[16] UTM lancar teknologi subkritikal pengurusan sampah pertama di Asia. (n.d.). Retrieved from http://www.utusan.com.my/sainsteknologi/inovasi/utm-lancar-teknologisubkritikal-pengurusan-sampah-pertama-di-asia1.647698

[17] United Nation. (2017). UN Calls on Malaysia to Champion Sustainable Development Goals. Retrieved from www.my.undp.org

[18] Universiti Sains Malaysia. (2015, Oktober 28). 'Zero Waste' Didik Warga Kampus Cara Pengurusnan Sisa. Retrieved from Universiti Sains Malayisa: https://news.usm.my/index.php/beritamutakhir/2909-zero-waste-didik-warga-kampuscara-pengurusan-sisa

[19] Utusan Online. (2014, Disember 9). ZWC- UM Pelihara Alam Sekitar. Retrieved from http://www.utusan.com.my/pendidikan/kampus/z wc-um-pulihara-alam-sekitar

[20] Utusan Online. (2018, Januari 24). UKM Sasar Kampus Sisa Sifar. Retrieved from http://www.utusan.com.my/sains-

teknologi/sains/ukm-sasar-kampus-sisa-sifar

[21] Weaver, J. (2014). Recommendations for Reducing Leaf and Yard Waste in Alberta Prepared for: Alberta Environment and Sustainable Resource Development. Retrieved from http://esrd.alberta.ca/

[22] Yard Trimmings Ban Impacts. (n.d.). Retrieved from https://compostingcouncil.org/wpcontent/uploads/2014/02/Yard-Trimmings-BanImpacts-and-Support-by-Dr.-Stuart-Buckner.pdf Deming, W. Edwards (1990). W. Edaward Deming (1990). Sample Design in Business Research. New York : Wiley-Interscience Publication 